\title{
Competitive Adsorption between Polyethylene Glycol and Acid Brilliant Red on Expanded Graphite
}

\author{
XIU-YAN PANG* and LI-LI ZHANG \\ College of Chemistry and Environmental Science, \\ Hebei University, Baoding 071002 People' Republic of China \\ pxy833@163.com
}

Received 19 August 2011; Accepted 4 October 2011

\begin{abstract}
Expanded graphite (EG) adsorbent was prepared with graphite as raw materials, potassium permanganate as oxidant, and vitriol as intercalation compound. Polyethylene glycol (PEG) 10000 and Acid brilliant red 3B (ABR) with obvious difference in molecular weights were selected as organic adsorbates, and their adsorption and competitive adsorption thermodynamics and kinetics on EG were investigated. The results are: In both single component system and dual component system, the adsorption and competitive adsorption isotherm of PEG 10000 and ABR on EG are all type I. In dual component system, the existence of another component would decrease the single component adsorbance, which might be caused by the competitive adsorption of these adsorbates for the same adsorbing site on EG. Adsorption and competitive adsorption are spontaneous, and the increase of ionic strength, temperature and expanded volume of the adsorbent would cause the increase of adsorbance. No matter the single component system or the dual component system, the adsorption kinetics models can all be well described with pseudo second-order model. Adsorption rate increases with the increase of temperature. Physical adsorption is the main action between EG with these adsorbates.
\end{abstract}

Keywords: Expanded graphite, Acid brilliant red 3B, Polyethylene glycol 10000, Competitive adsorption, Adsorption thermodynemics, Adsorption kinetics.

\section{Introduction}

Extensive use of dyes in industries such as textiles, paper, plastics, leather, food, cosmetic etc, often cause the formation of colored wastewater that require pretreatment prior to disposal into receiving water bodies. The used dyes are normally resistant to biodegradation and photodegradation. Polyethylene glycol (PEG) is a mild, low toxic substance and its waste water is produced in the preparative process of the surfactant, metal processing and surface treative process. PEG with high molecular weight is difficult to biodegrade by aerobic microorganisms in the water, it will consume a lot of dissolved oxygen and cause serious lack of oxygen and even result to water pollution.

In wastewater treatment, adsorption is a kind of effective measure used for the elimination of these contaminants. Active carbon $^{1-4}$, Mesoporous silica ${ }^{5-6}$, barrier discharge 
plasma $^{7}$, ion exchange resin ${ }^{8}$ and organobentonite ${ }^{[9]}$ have been tested in the treatment of organic molecules.

Expanded graphite (EG) is a new kind of adsorbent with abundant 4 levels pores with the size ranging from nanometer scale to micron scale ${ }^{[10]}$, and it has attracted attentions of scientist and engineers as for its high adsorption capacity to organic materials, such as heavy oil, dyes, aromatic sulfonates, PEG etc ${ }^{11-18}$. Actually, pollutants rarely exist solely in single component, but the adsorption research for them on EG often carried in single component system. So it is important to study the adsorption capacity of EG existing in dual or multicomponent system. The study can veritably reveal the characteristics of competitive adsorption on the same site, distribution and adsorbance difference caused by the physical or chemical interaction. The objective of the present research is to study dual component system competitive adsorption characteristics on EG with PEG 10000 and ABR as reference adsorbates, investigate its adsorption thermodynamics and kinetics characteristics.

\section{Experimental}

With the mass ratio of $1: 0.12: 5.0$ of $\mathrm{C}: \mathrm{KMnO}_{4}: \mathrm{H}_{2} \mathrm{SO}_{4}(96 \%)$, the definite amount of $\mathrm{C}$, $\mathrm{KMnO}_{4}$ and $\mathrm{H}_{2} \mathrm{SO}_{4}$ (diluted to a mass concentration of $75 \%$ with de-ionized water before mixed with graphite) are mixed under room temperature. Reaction lasting $30 \mathrm{~min}$ under stirring, then the products are washed with de-ionized water until $\mathrm{pH}$ reached to $6.0 \sim 7.0$. After filtration and dryness under $80^{\circ} \mathrm{C}$, the solid scalelike grains are heated under $900{ }^{\circ} \mathrm{C}$ for about $10 \mathrm{sec}$ and then $\mathrm{EG}$ can be gained. The expansion volume (EV) of unit mass $\mathrm{EG}$ is measured using measuring pot according to Standard of Expanded graphite GB10698-89 ${ }^{19}$. EGs with different EV are prepared using raw material graphite with different size of $0.3 \mathrm{~mm}, 0.18 \mathrm{~mm}$ and $0.15 \mathrm{~mm}$ as listed in Table 1. The specific surface, pore size distribution and pore cubage are detected with Micromeritics Instrument Corporation TriStar II 3020 V1.02 and pore structure parameters are calculated with BET method as listed in Table 1. In all the adsorption, competitive adsorption experiments, EG with an $\mathrm{EV}$ of $400 \mathrm{~mL} \cdot \mathrm{g}^{-1}$ is used as adsorbent except for the special illustration.

Table 1. Structural parameter of EGs.

\begin{tabular}{ccccc}
\hline $\begin{array}{c}\text { Materials } \\
\text { size, } \mathrm{mm}\end{array}$ & $\begin{array}{c}\mathrm{EV}, \\
\mathrm{mL} \cdot \mathrm{g}^{-1}\end{array}$ & $\begin{array}{c}\text { Total intrusion } \\
\text { volume } \mathrm{cm}^{3} \cdot \mathrm{g}^{-1}\end{array}$ & $\begin{array}{c}\text { Total pore area, } \\
\mathrm{m}^{2} \cdot \mathrm{g}^{-1}\end{array}$ & $\begin{array}{c}\text { Average pore } \\
\text { Diameter } \\
\text { 4V/A, nm }\end{array}$ \\
\hline 0.3 & 400 & 0.1009 & 34.35 & 11.61 \\
0.18 & 150 & 0.0698 & 23.84 & 11.61 \\
0.15 & 35 & 0.06263 & 21.30 & 11.59 \\
\hline
\end{tabular}

\section{Adsorbate characteristics}

PEG 10000 and ABR are used as reference compounds. The chemical structure and molecular weight are showed in Table 2. Simulated wastewaters of PEG 10000 and ABR in single component and in dual component are prepared by dissolving these adsorbates in deionized water at various concentrations. In quantitative analysis of PEG $10000{ }^{[20]}$, Dragendoff is used as colored reagent, and absorbance of the colored complex (color reaction lasted $10 \mathrm{~min}$ ) is detected with T6 New Century UV spectrophotometry (Puxi Tongyong Instrument Limited Company of Beijing). The absorption spectrum of ABR, PEG 10000 and the colored PEG 10000 are all detected as showed in Figure 1 and quantitative equations of them are listed in Table 3. 


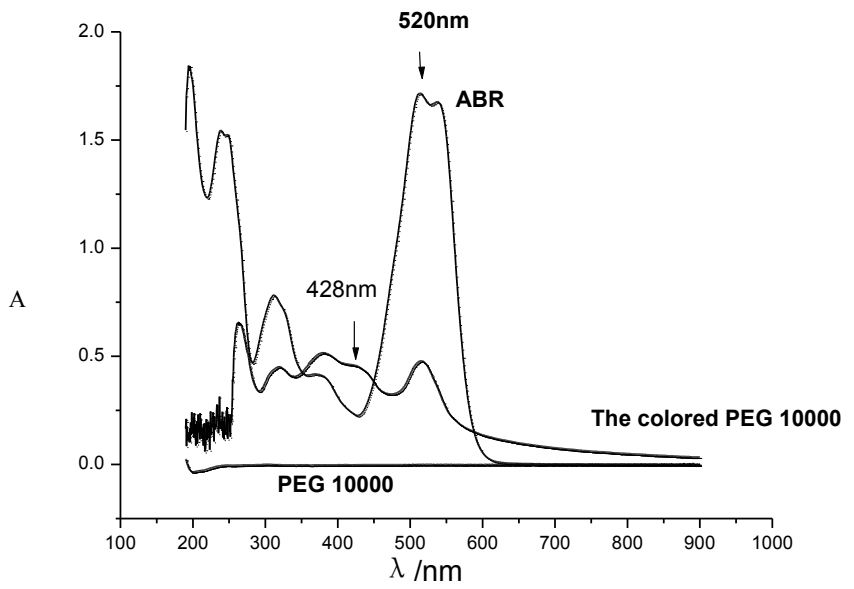

Figure 1. The absorption spectrum of ABR, PEG and the colored PEG.

Table 2. Chemical structure and molecular weight of the adsorbates.

\begin{tabular}{llcc}
\hline Adsorbates & Structure & Molecular weight & $\lambda_{\max }, \mathrm{nm}$ \\
\hline PEG 10000 & 10000 & 428 \\
\hline
\end{tabular}

Table 3. Quantitative equations of $A B R$ and $P E G^{\mathrm{a}}$.

\begin{tabular}{cccc}
\hline & $\lambda / \mathrm{nm}$ & Equation & $\mathrm{r}$ \\
\hline ABR & 520 & $\mathrm{Y}=0.01522+0.00739 \mathrm{x}$ & 0.9999 \\
& 428 & $\mathrm{Y}=0.02129+0.0009374 \mathrm{x}$ & 0.9998 \\
PEG10000 ( colored) & 428 & $\mathrm{Y}=0.00547+0.03121 \mathrm{x}$ & 0.9990 \\
\hline
\end{tabular}

a $x$-concentration of adsorbate, $m g \cdot L^{-1} ; Y$-absorbance.

\section{Methods}

Static adsorption in single system and dual component system

$0.20 \mathrm{~g}$ of EG is mixed in different conical glass flasks with $100.0 \mathrm{~mL}$ solution at the desired adsorbates concentration and ionic strength. Ionic strength is adjusted with $\mathrm{NaCl}$ or $\mathrm{Na}_{2} \mathrm{SO}_{4}$ solution. Mass of EG to volume of solution is standardized as $M / V=0.200 / 0.1=2.0 \mathrm{~g} \cdot \mathrm{L}^{-1}$, the equilibrium time for ABR is about $40 \mathrm{~h}$ and $40 \mathrm{~min}$ for PEG 10000, and it's not affected by adsorbate concentration. Absorbance and concentration changes of PEG 10000, ABR are recorded with spectrophotometer and calculated according to equation listed in Table 3 and adsorbance is calculated according to equation (1).

$$
q=V\left(C_{0^{-}} C\right) / M
$$

q: Adsorbance of adsorbate on $\mathrm{EG}, \mathrm{mg} \cdot \mathrm{g}^{-1} ; C_{0:}$ Initial concentration of adsorbate in solution, 
$\mathrm{mg} \cdot \mathrm{L}^{-1} ; C$ : Concentration of adsorbate in solution, $\mathrm{mg} \cdot \mathrm{L}^{-1} ; V$ : Volume of solution, $\mathrm{L} ; M$ : Mass of EG, g, When the adsorption reaches equilibrium state, $C$ can be written as $C_{e}$, and $q$ can be written as $q_{e}$.

\section{Adsorption capacity of EG under the influence of EV, ionic strength and temperature}

EGs with different EV are used to detect the influence of adsorbent structure on adsorption capacity, mass of EG to volume of solution is standardized as $M / V=0.200 / 0.1=2.0 \mathrm{~g} \cdot \mathrm{L}^{-1}$. $\mathrm{NaCl}$ and $\mathrm{Na}_{2} \mathrm{SO}_{4}$ are used to investigate influence on adsorbance. Different temperature of $5{ }^{\circ} \mathrm{C}, 25{ }^{\circ} \mathrm{C}$ and $45{ }^{\circ} \mathrm{C}$ are controlled in kinetic studies. Adsorbance and equilibrium adsorbance are calculated according to equation (1).

\section{Results and Discussion}

\section{Investigation of adsorption isotherm and thermodynamic parameter}

\section{Adsorption and competitive adsorption isotherm}

Static adsorption and competitive adsorption capacities of PEG 10000 and ABR are measured. As showed in Figure 2, typical I isotherms are observed under the tested condition, no matter in single system or dual component system of ABR and PEG 10000. But in dual component system, the existation of another adsorbate can decrease the adsorbate' adsorbance, which indicates that the same adsorption sites on EG are competed by ABR and PEG 10000. The influence on competitive adsorbence of PEG 10000 is more obvious than ABR, that might be caused by the smaller adsorption capacity of EG for PEG 10000.
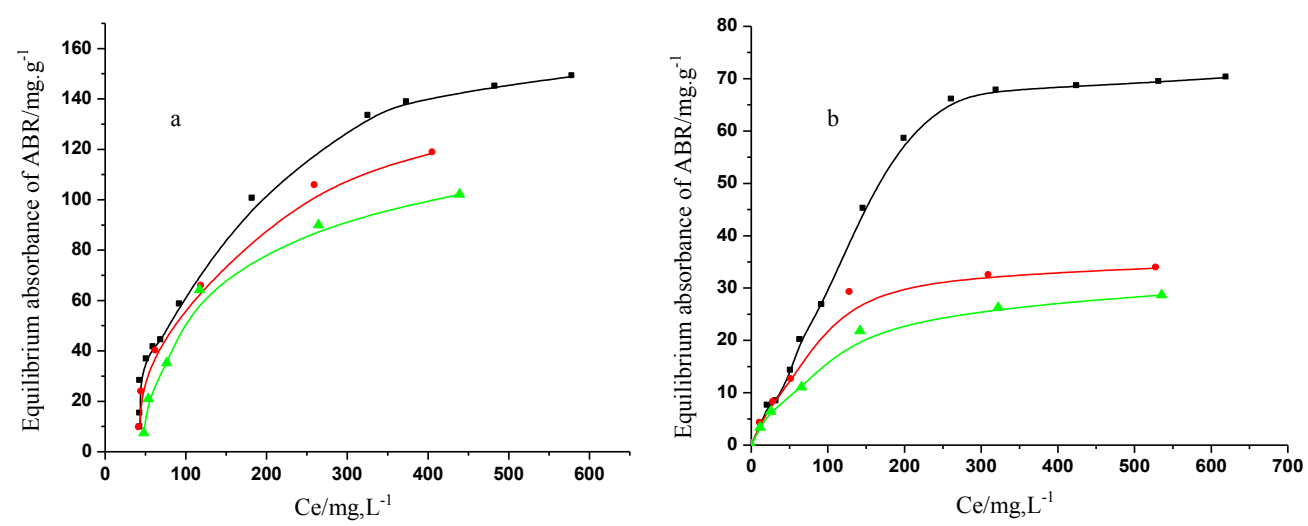

Figure 2. Adsorption and competitive adsorption isotherm of ABR and PEG (a) ABR (b) PEG 10000 (a) Concentrations of PEG 10000 are $(\bullet) 0 \mathrm{mg} \cdot \mathrm{L}^{-1} ;(\bullet) 100 \mathrm{mg} \cdot \mathrm{L}^{-1}$, ( $\left.\mathbf{\Delta}\right) 400$ $\mathrm{mg} \cdot \mathrm{L}^{-1}$ (b) Concentrations of ABR are (⿻) $0 \mathrm{mg} \cdot \mathrm{L}^{-1} ;(\bullet) 50 \mathrm{mg} \cdot \mathrm{L}^{-1}, \quad(\boldsymbol{\Delta}) 200 \mathrm{mg} \cdot \mathrm{L}^{-1}$.

To providing a description of adsorbate concentration and possible conformation in the interfacial region, Langmuir and Freundlich isotherm equations (2) and (3) are used to treat the isotherm data. As showed in Table 4, Langmuir equation has better linear relationship than Freundlich equation for single adsorption and competitive adsorption, which indicates that Langmuir adsorption model can preferably simulate the adsorption of PEG 10000 and ABR on EG. Meanwhile, existence of the second component causes the decrease of adsorbate' saturation absorbance compared with the single component system, which reveals 
that there are competitive adsorption between ABR and PEG 10000 on the same aperture sites, and the influence on competitive adsorbence of PEG 10000 is more obvious than ABR.

$$
\begin{aligned}
& \text { Langmuir equation: } q=q_{0} \cdot C /(A+C) \\
& \text { Freundlich equation: } \ln q_{e}=\ln K_{F}+(1 / n) \ln C e
\end{aligned}
$$

${ }^{*} K_{F}$-Freundlich equilibrium constant; $A$-Equilibrium concentration of adsorbate corresponding to half saturation adsorbance; $\mathrm{q}_{0}$-Saturation absorbance; $1 / \mathrm{n}$-Freundlich adsorption strength.

\begin{tabular}{|c|c|c|c|c|c|c|c|}
\hline \multirow{3}{*}{ 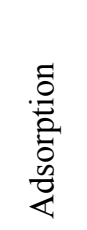 } & \multirow{2}{*}{ Adsorbates } & \multicolumn{3}{|c|}{ Langmuir } & \multicolumn{3}{|c|}{ Freundlich } \\
\hline & & $\mathrm{q}_{\mathrm{o}} \mathrm{mg} \cdot \mathrm{g}^{-1}$ & $\mathbf{A} \mathrm{mg} \cdot \mathrm{L}^{-1}$ & $\mathrm{r}$ & $\mathrm{K}_{\mathrm{F}}$ & $1 / \mathrm{n}$ & $\mathrm{r}$ \\
\hline & $\mathrm{ABR}$ & 274.0 & 356.4 & 0.995 & 0.2952 & 0.620 & 0.986 \\
\hline \multirow{5}{*}{ 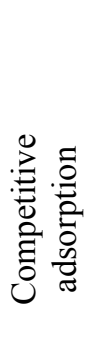 } & PEG 10000 & 200.4 & 182.0 & 0.996 & 3.073 & 0.977 & 0.995 \\
\hline & $\begin{array}{l}\text { PEG } 10000 \\
100 \mathrm{mg} \cdot \mathrm{L}^{-1}\end{array}$ & 219.3 & 282.0 & 0.999 & 0.5924 & 0.738 & 0.982 \\
\hline & $\begin{array}{l}\mathrm{PEG} 10000 \\
400 \mathrm{mg} \cdot \mathrm{L}^{-1}\end{array}$ & 130.6 & 120.5 & 0.999 & 0.5865 & 0.693 & 0.934 \\
\hline & ABR $50 \mathrm{mg} \cdot \mathrm{L}^{-1}$ & 42.72 & 114.6 & 0.996 & 1.926 & 0.819 & 0.998 \\
\hline & ABR $200 \mathrm{mg} \cdot \mathrm{L}^{-1}$ & 31.88 & 98.83 & 0.998 & 1.041 & 0.573 & 0.980 \\
\hline
\end{tabular}

Table 4. Langmuir and Freundlich isotherm constants at $25^{\circ} \mathrm{C}$.

Adsorption free energy changes $(\Delta G)$ are calculated according to equation (4). Negative $(\Delta \mathrm{G})$ (showed in Table 5) indicate that adsorption and competivition adsorption of these reference compounds on EG are all spontaneous.

$$
\Delta \mathrm{G}^{\circ}=-\mathrm{R} \mathrm{T} \ln (\mathrm{b}), \quad(\mathrm{b}=1 / \mathrm{A})
$$

b- Langmuir equation constant, $\mathrm{mL} \cdot \mathrm{mg}^{-1} ; \Delta \mathrm{G}^{\circ}$ - Free energy change in the adsorption

Table 5. Free energy change of adsorption and competivition adsorption at $25^{\circ} \mathrm{C}$

\begin{tabular}{ccccccc}
\hline & \multicolumn{3}{c}{ Adsorption } & \multicolumn{4}{c}{ Competitive adsorption } \\
\hline & ABR & PEG & PEG 10000 & PEG 10000 & ABR & ABR \\
$\Delta \mathrm{G}^{\circ} \mathrm{kJ} \cdot \mathrm{mol}^{-1}$ & -14.32 & -11.68 & -11.56 & -11.20 & -13.75 & -11.68 \\
\hline
\end{tabular}

\section{Influence of EG kinds on adsorption and competitive adsorption capacity}

Adsorption and competitive adsorption research are carried out using different EGs listed in Table 1 as adsorbent. As showed in Figure 3 and Figure 4, the increase of EV of these adsorbents enhance the increase of adsorbance in single system and dual component system of ABR and PEG 10000, but it has no influence on adsorption isotherm.

\section{Influence of ionic strength on adsorption and competitive adsorption capacity}

$\mathrm{NaCl}$ and $\mathrm{Na}_{2} \mathrm{SO}_{4}$ is used respectively to adjust solution ionic strength in the range of 0 to $0.35 \mathrm{mg} \cdot \mathrm{L}^{-1}$ with the concentration of ABR, PEG $10000 \mathrm{keeping} 400 \mathrm{mg} \cdot \mathrm{L}^{-1}$. Influence of ionic strength on adsorbance (showed in Figure 5 and Figure 6) indicate that presence of salt 
ions can improve the adsorption capacity of EG for these adsorbates, and it may be caused by increase of hydrophobic attraction of adsorbates due to the "salting-out" effect.

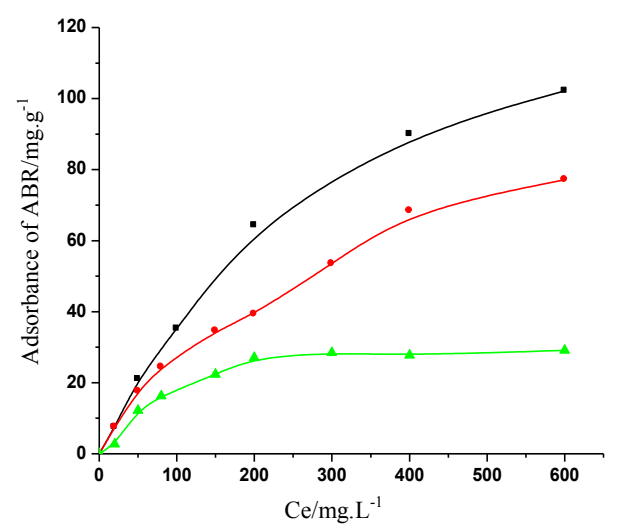

Figure 3. Influence of adsorbent' EV on competitive adsorption adsorbance of ABR Concentration of PEG is $400 \mathrm{mg} \cdot \mathrm{L}^{-1}$; EV of EG is $(\mathbf{\bullet}) 400 \mathrm{~mL} \cdot \mathrm{g}^{-1},(\bullet) 150 \mathrm{~mL} \cdot \mathrm{g}^{-1},(\mathbf{\Delta}) 35$ $\mathrm{mL} \cdot \mathrm{g}^{-1}$

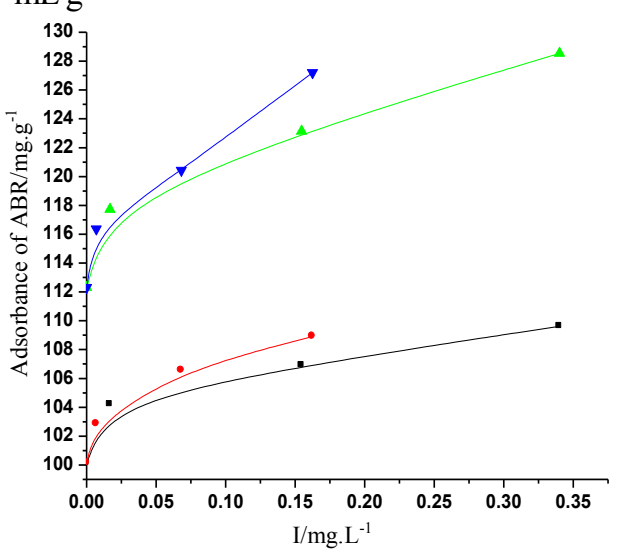

Figure 5. Influence of ionic strength on adsorption and competitive adsorption capacity of EG for ABR ( $)$ ( $)$ ( $)$ Single

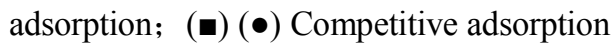
$(\boldsymbol{\Delta})(\boldsymbol{\bullet}) \mathrm{NaCl} ;(\bullet)(\boldsymbol{\nabla}) \mathrm{Na}_{2} \mathrm{SO}_{4}$

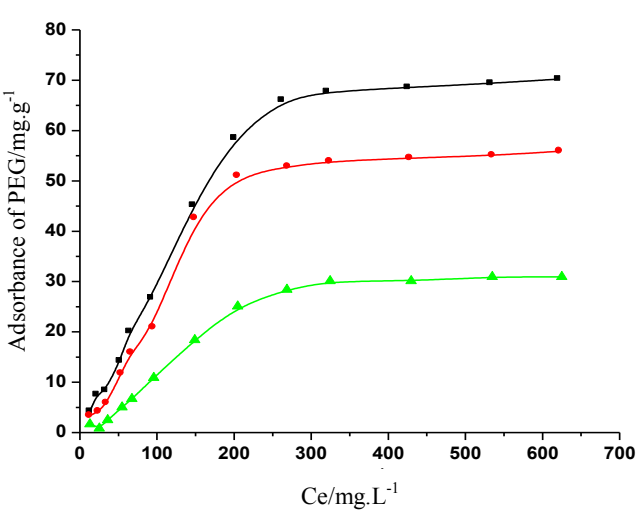

Figure 4. Influence of adsorbent' $\mathrm{EV}$ on competitive adsorbance of PEG 10000 Concentration of ABR is $400 \mathrm{mg} \cdot \mathrm{L}^{-1}$; EV of EG is (•) $400 \mathrm{~mL}^{-1} \mathrm{~g}^{-1},(\bullet) 150 \mathrm{~mL} \cdot \mathrm{g}^{-1}, \quad(\boldsymbol{\Delta}) 35 \mathrm{~mL} \cdot \mathrm{g}^{-}$

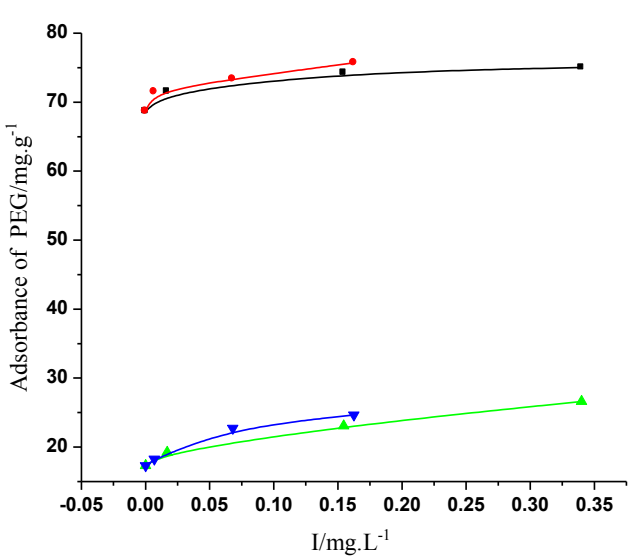

Figure 6. Influence of ionic strength on adsorption and competitive adsorption capacity of EG for PEG $10000(\boldsymbol{\nabla})(\boldsymbol{\Delta})$ Single adsorption; (घ) (•) Competitive adsorption $(\boldsymbol{\Delta})(\boldsymbol{\bullet}) \mathrm{NaCl} ;(\bullet)(\boldsymbol{\nabla}) \mathrm{Na}_{2} \mathrm{SO}_{4}$

\section{Investigation of kinetics parameter of adsorption and competitive adsorption}

\section{Influence of adsorbate concentration and temperature on adsorption kinetics}

Adsorbance of adsorbate on EG is a function of time and adsorbate concentration. As showed in Figure 7 and Figure 8, in the early stage of the adsorption, the adsorbance increased with time, the equilibrium time for ABR is about $40 \mathrm{~h}$, and $40 \mathrm{~min}$ for PEG 10000. The equilibrium adsorbances have a little increase with the increase of temperature no matter for single system or competitive system. The results might be caused by the decrease 
of adsorbates dissolubility in water with the increase of temperature.

Adsorption and competitive adsorption kinetic models

The dynamics data of adsorption and competitive adsorption is characterized by pseudo First-order model (equation 5) and pseudo Second-order model (equation 6) ${ }^{21,22}$.

First-order model: $\ln \left(q_{e}-q\right)=\ln q_{e}-k t$

Second-order model: $t / q=1 /\left(k q_{e}^{2}\right)+t / q_{e}$

Since $q$ reaches $q_{\mathrm{e}}$ at equilibrium, $q$ values smaller than $0.9 q_{\mathrm{e}}$ are used for analysis. Plots of $\ln \left(q_{\mathrm{e}}-q\right)$ versus $t$ and $t / q$ versus $t$ are used to test the first- and second-order models, and the fitting results are given in Table 6 9. Both line curve fit and $q_{\mathrm{e}, \text { cal }}$, second-order model gives more well results than first-order model. So the kinetics parameter of both adsorption and competitive adsorption can all be described by Second-order model. In addition, there is not obvious correlation between adsorption rate constant and the adsorption temperature. Based on Second-order model, equation (7) and equation (8), adsorption rate and half adsorption time of these adsorbates are calculated.
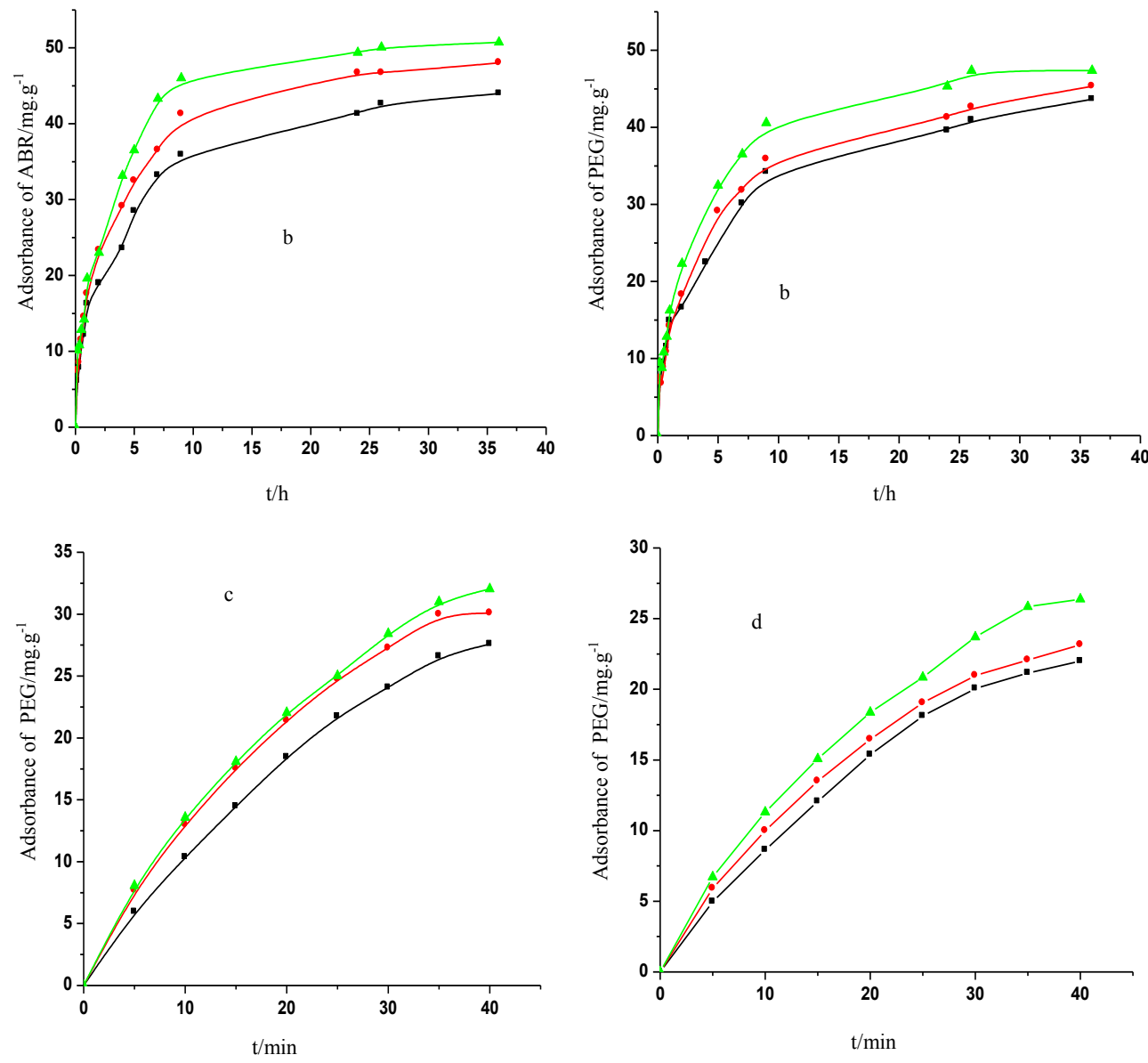

Figure 7. Influence of temperature on adsorbance in single system and competitive system with adsorbates' initinal concentration of $100 \mathrm{mg} \cdot \mathrm{L}^{-1}(\boldsymbol{\bullet}) 5{ }^{\circ} \mathrm{C},(\bullet) 25{ }^{\circ} \mathrm{C},(\mathbf{\Delta}) 45^{\circ} \mathrm{C}$ (a) Single system of ABR (b) Competitive adsorption of PEG 10000 for ABR (c) Single system of PEG 10000 (d) Competitive adsorption of ABR for PEG 10000. 

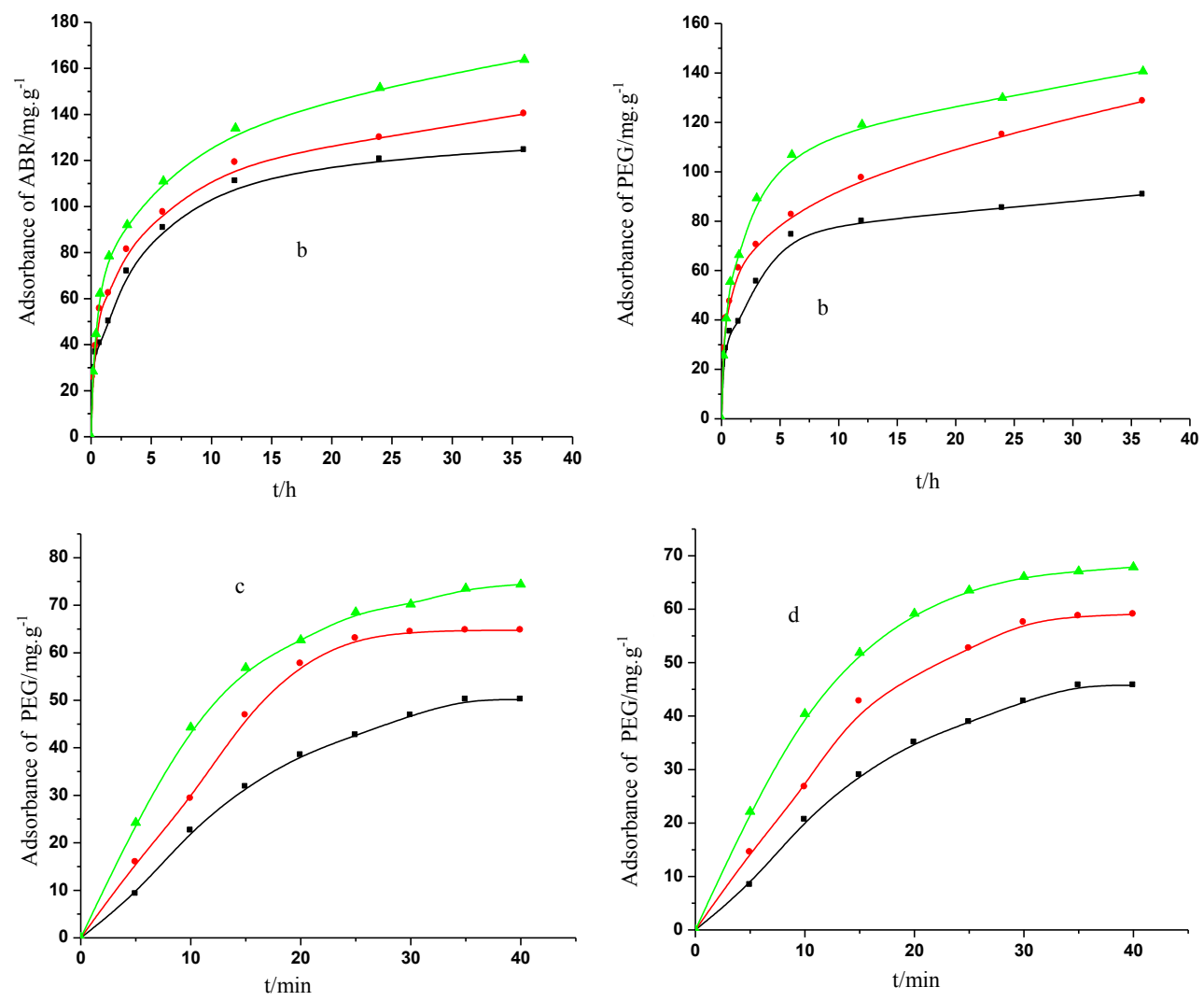

Figure 8. Influence of temperature on adsorbance in single system and competitive system with adsorbates' initinal concentration of $400 \mathrm{mg} \cdot \mathrm{L}^{-1}(\mathbf{\bullet}) 5{ }^{\circ} \mathrm{C},(\bullet) 25{ }^{\circ} \mathrm{C},(\boldsymbol{\Delta}) 45^{\circ} \mathrm{C}$ (a) Single system of ABR (b) Competitive adsorption of PEG 10000 for ABR (c) Single system of PEG 10000 (d) Competitive adsorption of ABR for PEG 10000.

Table 6. Comparison of the adsorption kinetic models of ABR.

\begin{tabular}{|c|c|c|c|c|c|c|c|c|}
\hline \multirow[b]{2}{*}{$\mathrm{C}_{0} \mathrm{mg} \cdot \mathrm{L}^{-1}$} & \multirow[b]{2}{*}{$\begin{array}{c}\mathrm{T} \\
\left({ }^{\circ} \mathrm{C}\right)\end{array}$} & \multirow[b]{2}{*}{$\begin{array}{l}\mathrm{q}_{\mathrm{e}, \mathrm{exp}}, \\
\mathrm{mg} \cdot \mathrm{g}^{-1}\end{array}$} & \multicolumn{3}{|c|}{ First-order } & \multicolumn{3}{|c|}{ Second-order } \\
\hline & & & $\begin{array}{c}\mathrm{q}_{\mathrm{e}, \mathrm{cal}}, \\
\mathrm{mg} \cdot \mathrm{g}^{-1}\end{array}$ & $\begin{array}{c}\mathrm{k} \\
\min ^{-1} \\
\end{array}$ & $r$ & $\begin{array}{l}\mathrm{q}_{\mathrm{e}, \mathrm{cal}}, \\
\mathrm{mg} \cdot \mathrm{g}^{-1}\end{array}$ & $\begin{array}{l}\mathrm{k} / 10^{-3} \mathrm{~g}^{-1}, \\
\mathrm{mg} \cdot \mathrm{min}^{-1}\end{array}$ & $\mathrm{r}$ \\
\hline \multirow{5}{*}{100} & \multirow{2}{*}{5} & \multirow{2}{*}{43.98} & $33.26 \pm$ & $0.119 \pm$ & \multirow{2}{*}{-0.982} & $46.06 \pm$ & $9.43 \pm$ & \multirow{2}{*}{0.998} \\
\hline & & & 1.074 & 0.0069 & & 0.00041 & 0.0011 & \\
\hline & \multirow{2}{*}{25} & \multirow{2}{*}{48.04} & $41.13 \pm$ & $0.049 \pm$ & \multirow{2}{*}{-0.946} & $50.43 \pm$ & $9.73 \pm$ & \multirow{2}{*}{0.999} \\
\hline & & & 1.05 & 0.0050 & & 0.00027 & 0.0018 & \\
\hline & 45 & 50.74 & $\begin{array}{c}45.87 \pm \\
1.11\end{array}$ & $\begin{array}{c}0.153 \pm \\
0.010\end{array}$ & -0.976 & $\begin{array}{c}53.19 \pm \\
0.00024\end{array}$ & $\begin{array}{l}10.68 \pm \\
0.0018\end{array}$ & 0.999 \\
\hline \multirow{3}{*}{400} & 5 & 124.49 & $\begin{array}{c}93.99 \pm \\
1.099\end{array}$ & $\begin{array}{c}0.1058 \pm \\
0.102\end{array}$ & -0.969 & $\begin{array}{c}133.51 \pm \\
0.000003\end{array}$ & $\begin{array}{c}2.89 \pm \\
0.00010\end{array}$ & 0.999 \\
\hline & 25 & 146.14 & $102.42 \pm$ & $0.08638 \pm$ & -0.951 & $148.15 \pm$ & $3.44 \pm$ & 0.996 \\
\hline & 45 & 163.73 & $\begin{array}{c}116.06 \pm \\
1.089\end{array}$ & $\begin{array}{c}0.1004 \pm \\
0.009\end{array}$ & -0.972 & $\begin{array}{l}157.48 \pm \\
0.00020\end{array}$ & $\begin{array}{c}4.19 \pm \\
0.00087\end{array}$ & 0.997 \\
\hline
\end{tabular}


Table 7. Comparison of the adsorption kinetic models of PEG.

\begin{tabular}{|c|c|c|c|c|c|c|c|c|}
\hline \multirow{2}{*}{$\begin{array}{l}\mathrm{C}_{0} \\
\mathrm{mg} \cdot \mathrm{L}^{-}\end{array}$} & \multirow[b]{2}{*}{$\begin{array}{c}\mathrm{T} \\
\left({ }^{\circ} \mathrm{C}\right)\end{array}$} & \multirow[b]{2}{*}{$\begin{array}{l}\mathrm{q}_{\mathrm{e}, \exp } \\
\mathrm{mg} \cdot \mathrm{g}^{-1}\end{array}$} & \multicolumn{3}{|c|}{ First-order } & \multicolumn{3}{|c|}{ Second-order } \\
\hline & & & $\begin{array}{c}\mathrm{q}_{\mathrm{e}, \mathrm{cal}} \\
\mathrm{mg} \cdot \mathrm{g}^{-1}\end{array}$ & $\mathrm{~K}, \min ^{-1}$ & $\mathrm{r}$ & $\begin{array}{l}\mathrm{q}_{\mathrm{e}, \mathrm{cal}},{ }^{-1} \\
\mathrm{mg} \cdot \mathrm{g}^{-1}\end{array}$ & $\begin{array}{l}\mathrm{k} / 10^{-5} \mathrm{~g} \cdot \\
\mathrm{mg} \cdot \mathrm{min}^{-1}\end{array}$ & $\mathrm{r}$ \\
\hline \multirow{4}{*}{100} & 5 & 27.58 & $\begin{array}{c}35.91 \pm \\
1.27\end{array}$ & $\begin{array}{c}0.07 \pm \\
0.013\end{array}$ & $0 . \overline{9} 29$ & $\begin{array}{l}30.30 \pm \\
0.0008\end{array}$ & $\begin{array}{c}1.4 \pm \\
0.00003\end{array}$ & 0.992 \\
\hline & 25 & 30.09 & $36.52 \pm$ & $0.086 \pm$ & - & $34.49 \pm$ & $1.5 \pm$ & 0.995 \\
\hline & & & $\begin{array}{l}1.16 \\
45.44 \pm\end{array}$ & $\begin{array}{c}0.01 \\
0.08 \pm\end{array}$ & $\begin{array}{c}0.9 / 4 \\
-\end{array}$ & $\begin{array}{l}0.000 / \\
37.09 \pm\end{array}$ & $\begin{array}{l}0.000 / \\
1.5 \pm\end{array}$ & \\
\hline & 45 & 32.04 & 1.24 & 0.011 & 0.950 & 0.0006 & 0.00002 & 0.997 \\
\hline \multirow{3}{*}{400} & 5 & 50.15 & $\begin{array}{c}61.37 \pm \\
1.13\end{array}$ & $0.09 \pm 0.007$ & $0 . \overline{986}$ & $\begin{array}{l}54.79 \pm \\
0.0002\end{array}$ & $\begin{array}{c}1.1 \pm \\
0.00007\end{array}$ & 0.999 \\
\hline & 25 & 64.70 & $\begin{array}{c}67.9 \pm \\
1.52\end{array}$ & $\begin{array}{l}0.17 \pm \\
0.023\end{array}$ & $\begin{array}{c}- \\
0.957\end{array}$ & $\begin{array}{l}63.73 \pm \\
0.0007\end{array}$ & $\begin{array}{c}1.3 \pm \\
0.00007\end{array}$ & 0.993 \\
\hline & 45 & 74.39 & $\begin{array}{c}78.70 \pm \\
1.05\end{array}$ & $\begin{array}{l}0.10 \pm \\
0.003\end{array}$ & $0 . \overline{998}$ & $\begin{array}{l}74.13 \pm \\
0.0003\end{array}$ & $\begin{array}{c}1.6 \pm \\
0.0003\end{array}$ & 0.998 \\
\hline
\end{tabular}

Table 8. Comparison of the kinetic models of ABR under the competitive adsorption of PEG ${ }^{\mathrm{b}}$.

\begin{tabular}{|c|c|c|c|c|c|c|c|c|}
\hline \multirow[b]{2}{*}{$\begin{array}{c}\mathrm{C}_{0} \\
\mathrm{mg} \cdot \mathrm{L}^{-1}\end{array}$} & \multirow[b]{2}{*}{$\begin{array}{l}\mathrm{T} \\
{ }^{\circ} \mathrm{C}\end{array}$} & \multirow[b]{2}{*}{$\begin{array}{c}\mathrm{q}_{\mathrm{e}, \exp } \\
\mathrm{mg} \cdot \mathrm{g}^{-1}\end{array}$} & \multicolumn{3}{|c|}{ First-order } & \multicolumn{3}{|c|}{ Second-order } \\
\hline & & & $\begin{array}{c}\mathrm{q}_{\mathrm{e}, \mathrm{cal}} \\
\mathrm{mg} \cdot \mathrm{g}^{-1}\end{array}$ & $\underset{\min ^{-1}}{\mathrm{~K}}$ & $\mathrm{r}$ & $\begin{array}{c}\mathrm{q}_{\mathrm{e}, \mathrm{cal}} \\
\mathrm{mg} \cdot \mathrm{g}^{-1}\end{array}$ & $\begin{array}{c}\mathrm{k} / 10^{-3} \mathrm{~g} \cdot \\
\mathrm{mg}^{-1} \cdot \mathrm{min}^{-1}\end{array}$ & $\mathrm{r}$ \\
\hline \multirow{3}{*}{100} & 5 & 44.65 & $\begin{array}{c}31.96 \pm \\
1.07\end{array}$ & $\begin{array}{c}0.098 \pm \\
0.006\end{array}$ & -0.978 & $\begin{array}{l}44.68 \pm \\
0.0007\end{array}$ & $\begin{array}{c}9.46 \pm \\
0.0013\end{array}$ & 0.995 \\
\hline & 25 & 45.33 & $\begin{array}{c}33.24 \pm \\
1.09\end{array}$ & $\begin{array}{c}0.098 \pm \\
0.008\end{array}$ & -0.965 & $\begin{array}{l}45.37 \pm \\
0.0005\end{array}$ & $\begin{array}{c}9.95 \pm \\
0.0010\end{array}$ & 0.998 \\
\hline & 45 & 47.36 & $\begin{array}{c}34.16 \pm \\
1.09\end{array}$ & $\begin{array}{c}0.131 \pm \\
0.011\end{array}$ & -0.964 & $\begin{array}{l}49.73 \pm \\
0.0004\end{array}$ & $\begin{array}{l}10.19 \pm \\
0.0011\end{array}$ & 0.998 \\
\hline \multirow{3}{*}{400} & 5 & 90.66 & $\begin{array}{c}59.09 \pm \\
1.15\end{array}$ & $\begin{array}{c}0.113 \pm \\
0.015\end{array}$ & -0.942 & $\begin{array}{l}94.97 \pm \\
0.0002\end{array}$ & $\begin{array}{c}5.01 \pm \\
0.0006\end{array}$ & 0.999 \\
\hline & 25 & 128.55 & $\begin{array}{c}79.66 \pm \\
1.08\end{array}$ & $\begin{array}{c}0.083 \pm \\
0.008\end{array}$ & -0.967 & $\begin{array}{l}129.8 \pm \\
0.0003\end{array}$ & $\begin{array}{c}3.87 \pm \\
0.0015\end{array}$ & 0.995 \\
\hline & 45 & 140.73 & $\begin{array}{c}93.48 \pm \\
1.13\end{array}$ & $\begin{array}{c}0.113 \pm \\
0.014\end{array}$ & -0.953 & $\begin{array}{c}143.06 \pm \\
0.001\end{array}$ & $\begin{array}{c}4.45 \pm \\
0.0009\end{array}$ & 0.999 \\
\hline
\end{tabular}

${ }^{b} \overline{\text { The concentrations of competitive component PEG } 10000 \text { are } 100 \mathrm{mg} \cdot \mathrm{L}^{-1} \text { and } 400 \mathrm{mg} \cdot \mathrm{L}^{-1} \text {, respectively. }}$.

Table 9. Comparison of the kinetic models of PEG under the competitive adsorption of $\mathrm{ABR}^{\mathrm{c}}$.

\begin{tabular}{|c|c|c|c|c|c|c|c|c|}
\hline \multirow[b]{2}{*}{$\begin{array}{c}\mathrm{C}_{0}, \\
\mathrm{mg} \cdot \mathrm{L}^{-1}\end{array}$} & \multirow[b]{2}{*}{$\begin{array}{l}\mathrm{T}, \\
{ }^{\circ} \mathrm{C}\end{array}$} & \multirow[b]{2}{*}{$\begin{array}{l}\mathrm{q}_{\mathrm{e}, \mathrm{exp}}-1 \\
\mathrm{mg} \cdot \mathrm{g}^{-1}\end{array}$} & \multicolumn{3}{|c|}{ First-order } & \multicolumn{3}{|c|}{ Second-order } \\
\hline & & & $\begin{array}{c}\mathrm{q}_{\mathrm{e}, \mathrm{cal}} \\
\mathrm{mg} \cdot \mathrm{g}^{-1}\end{array}$ & $\begin{array}{c}\mathrm{k} / 10^{-3} \\
\min ^{-1}\end{array}$ & $r$ & $\begin{array}{c}\mathrm{q}_{\mathrm{e}, \mathrm{cal}}, 1 \\
\mathrm{mg} \cdot \mathrm{g}^{-1}\end{array}$ & $\begin{array}{l}\mathrm{k} / 10^{-3}, \mathrm{~g} \cdot \\
\mathrm{mg} \cdot \mathrm{min}^{-1}\end{array}$ & $r$ \\
\hline \multirow{3}{*}{100} & 5 & 6.47 & $\begin{array}{c}4.71 \pm \\
1.15\end{array}$ & $\begin{array}{c}4.3 \pm \\
0.00072\end{array}$ & $\begin{array}{c}- \\
0.883\end{array}$ & $\begin{array}{c}6.01 \pm \\
0.0034\end{array}$ & $\begin{array}{c}3.6 \pm \\
0.0034\end{array}$ & 0.993 \\
\hline & 25 & 7.83 & $\begin{array}{c}5.06 \pm \\
1.13\end{array}$ & $\begin{array}{c}3.8 \pm \\
0.0006\end{array}$ & $\begin{array}{c}- \\
0.892\end{array}$ & $\begin{array}{l}7.028 \pm \\
0.0013\end{array}$ & $\begin{array}{c}7.8 \pm \\
0.0013\end{array}$ & 1.0 \\
\hline & 45 & 10.39 & $\begin{array}{l}5.9 \pm \\
1.05\end{array}$ & $\begin{array}{c}3.7 \pm \\
0.00026\end{array}$ & $0 . \overline{9}$ & $\begin{array}{c}11.250 \pm \\
0.0066\end{array}$ & $\begin{array}{c}8.6 \pm \\
0.0066\end{array}$ & 0.992 \\
\hline \multirow{3}{*}{400} & 5 & 8.54 & $\begin{array}{c}6.96 \pm \\
1.09\end{array}$ & $\begin{array}{c}4.5 \pm \\
0.0004\end{array}$ & $0 . \overline{974}$ & $\begin{array}{c}9.95 \pm \\
0.00028\end{array}$ & $\begin{array}{c}3.1 \pm \\
0.0028\end{array}$ & 0.956 \\
\hline & 25 & 10.21 & $\begin{array}{c}8.51 \pm \\
1.06\end{array}$ & $\begin{array}{c}4.8 \pm \\
0.0003\end{array}$ & $0 . \overline{979}$ & $\begin{array}{l}10.23 \pm \\
0.0043\end{array}$ & $\begin{array}{c}4.3 \pm \\
0,0042\end{array}$ & 0.995 \\
\hline & 45 & 12.10 & $\begin{array}{c}11.88 \pm \\
1.05\end{array}$ & $\begin{array}{c}4.9 \pm \\
0.00026\end{array}$ & $0 . \overline{986}$ & $\begin{array}{l}12.96 \pm \\
0.0081\end{array}$ & $\begin{array}{c}5.8 \pm \\
0.0081\end{array}$ & 0.998 \\
\hline
\end{tabular}

\footnotetext{
${ }^{c}$ The concentrations of competitive component $A B R$ are $100 \mathrm{mg} \cdot \mathrm{L}^{-1}$ and $400 \mathrm{mg} \cdot \mathrm{L}^{-1}$, respectively.
} 
848 XIU-YAN PANG et al.

$$
\begin{gathered}
u=k q_{e}{ }^{2} \\
t_{1 / 2}=1 /\left(k q_{e}\right)
\end{gathered}
$$

$u$ : Initial adsorption rate, $(\mathrm{mg} / \mathrm{g} \cdot \mathrm{min}) ; t_{1 / 2}$ : Half-adsorption time, (min) for PEG 10000 and (h) for ABR. As showed in Table 10 12, $u$ is found to increase with the increase of adsorbates, initial concentration and temperature and $t_{1 / 2}$ decrease with the increase of temperature.

Table 10. Kinetic parameters for the second-order model of ABR in single system.

\begin{tabular}{cccccc}
\hline $\mathrm{C}_{0} \mathrm{mg} \cdot \mathrm{L}^{-1}$ & $\mathrm{~T}^{\circ} \mathrm{C}$ & $\mathrm{u} \mathrm{mg} \cdot \mathrm{g}^{-1} \cdot \mathrm{min}^{-1}$ & $\mathrm{t}_{1 / 2} \mathrm{~h}$ & $\mathrm{E}_{\mathrm{a}} \mathrm{kJ} \cdot \mathrm{mol}^{-1}$ & $\mathrm{r}$ \\
\hline \multirow{3}{*}{100} & 5 & 10.38 & 3.20 & & \\
& 25 & 12.98 & 2.81 & 2.27 & -0.948 \\
& 45 & 20.03 & 2.16 & & \\
400 & 5 & 44.75 & 2.78 & & \\
& 25 & 73.50 & 1.99 & 6.72 & -0.997 \\
\hline
\end{tabular}

Table 11. Kinetic parameters for the second-order model of PEG in single system.

\begin{tabular}{cccccc}
\hline $\mathrm{C}_{0} \mathrm{mg} \cdot \mathrm{L}^{-1}$ & $\mathrm{~T}^{\circ} \mathrm{C}$ & $\mathrm{u} \mathrm{mg} \cdot \mathrm{g}^{-1} \mathrm{~min}^{-1}$ & $\mathrm{t}_{1 / 2} \mathrm{~min}$ & $\mathrm{E}_{\mathrm{a}} \mathrm{kJ} \cdot \mathrm{mol}^{-1}$ & $\mathrm{r}$ \\
\hline \multirow{3}{*}{100} & 5 & 1.07 & 25.84 & & \\
& 25 & 1.33 & 22.63 & 7.35 & -0.997 \\
& 45 & 1.54 & 20.78 & & \\
400 & 5 & 2.75 & 18.21 & & \\
& 25 & 5.54 & 11.67 & 1.27 & -0.987 \\
& 45 & 9.04 & 8.16 & & \\
\hline
\end{tabular}

\begin{tabular}{|c|c|c|c|c|}
\hline \multicolumn{2}{|c|}{$\mathrm{C}_{0} \mathrm{mg} \cdot \mathrm{L}^{-1}$} & $\mathrm{~T}^{\circ} \mathrm{C}$ & $\mathrm{u} \mathrm{mg} \cdot \mathrm{g}^{-1} \mathrm{~min}^{-1}$ & $\mathrm{t}_{1 / 2(\mathrm{ABR})} / \mathrm{ht}_{1 / 2(\mathrm{PEG})} / \mathrm{min}$ \\
\hline \multirow{6}{*}{$\frac{\alpha}{m}$} & \multirow{3}{*}{100} & 5 & 9.16 & 3.40 \\
\hline & & 25 & 10.07 & 3.16 \\
\hline & & 45 & 13.60 & 2.69 \\
\hline & \multirow{3}{*}{400} & 5 & 41.15 & 2.20 \\
\hline & & 25 & 63.91 & 2.01 \\
\hline & & 45 & 88.86 & 1.58 \\
\hline \multirow{6}{*}{$\begin{array}{l}8 \\
8 \\
0 \\
0 \\
0 \\
\text { 崩 }\end{array}$} & \multirow{3}{*}{100} & 5 & 0.94 & 27.06 \\
\hline & & 25 & 1.21 & 24.37 \\
\hline & & 45 & 1.38 & 22.54 \\
\hline & \multirow{3}{*}{400} & 5 & 2.26 & 20.41 \\
\hline & & 25 & 5.13 & 13.30 \\
\hline & & 45 & 8.46 & 10.65 \\
\hline
\end{tabular}

Table 12. Kinetic parameters for the second-order model in dual component system ${ }^{\mathrm{d}}$.

${ }^{d}$ The concentrations of competitive component are $100 \mathrm{mg} \cdot \mathrm{L}^{-1}$ and $400 \mathrm{mg} \cdot \mathrm{L}^{-1}$, respectively. 
Second-order rate constants are used to calculate adsorption activation energy according to equation (9). Results listed in Table 10 11 show that the activation energy in adsorption are all lower than $40 \mathrm{~kJ} \cdot \mathrm{mol}^{-1}$, which indicates that adsorption of the reference compounds on EG are mainly physical adsorption.

$$
\operatorname{Lnk}=\operatorname{Ln} A-E_{a} /(R T)
$$

$A$ : The re-exponential factor, $\left(\mathrm{g} \cdot \mathrm{mg}^{-1} \cdot \mathrm{min}^{-1}\right) ; E a$ : The activation energy of adsorption, $\left(\mathrm{kJ} \cdot \mathrm{mol}^{-1}\right)$.

\section{Conclusion}

This study has provided an insight into the adsorption and competitive adsorption isotherm, thermodynamic parameter, kinetic model and parameter of EG for ABR and PEG 10000. The results are summarized as follows:

EG has adsorption capacity for both PEG 10000 and ABR, the adsorption and competitive adsorption isotherm of these adsorbates on EG are all type I. In competitive adsorption of dual component system, the existence of another component would decrease the adsorbance of EG for single adsorbate, which might be caused by the competitive adsorption for the same adsorbing site on EG. Adsorption and competitive adsorption of PEG 10000 and ABR on EG are all spontaneous, and the increase of ionic strength, temperature and EV of adsorbent would cause the increase of EG adsorption capacity. No matter single adsorption or competitive adsorption of dual component system, the adsorption kinetics models can all be well described with pseudo second-order kinetics model. Physical adsorption is the main action between EG with PEG or EG with ABR.

\section{References}

1. Barton S S, Carbon, 1981, 19(5), 353.

2. Gurses A, Yalcin M, Sozbilir M and Dogar C, Fuel Process Technol., 2003, 81(1), 57.

3. Guo L and Wu Z S, Acta Phys-Chim Sin., 2008, 24(5), 737.

4. Derylo-Marczewska A, Buczek B and Swiatkowski A, Appl Surf Sci., 2011, 257(22), 9466.

5. Xue X M and Li F T, Micropor Mesopor Mat., 2008, 116(1-3), 116.

6. Huang H Y, Yang C L, Zhang H X and Liu M C, Micropor Mesopor Mat., 2008, 111(1-3), 254.

7. Qu G Z, Lu N, Li J, Wu Y, Li G F and Li D, J Hazard Mater., 2009, 172(1), 472.

8. Rengaraj S, Yeon J W, Kim Y, Jung Y, Ha Y K and Kim W H, J Hazard Mater., 2007, 143(1-2), 469.

9. $\quad$ Ma J F, Cui B Y, Dai J and Li D L, J Hazard Mater., 2011, 186(2-3), 1758.

10 Zhao H, Zhou W, Shen W C and Kang F Y, Mater Sci Eng., 2002, 20(2), 153.

11. Kang F Y, Zheng Y P, Zhao H, Wang H N, Wang L N, Shen W C and Inagaki M, New Carbon Mater., 2003, 18(3), 161.

12. Toyoda M, Moriya K, Aizawa J I, Konno H and Inagaki M, Desalination, 2000, 128(3), 205.

13. Inagaki M, Konno H, Toyoda M, Moriya K and Kihara T, Desalination, 2000, 128(3), 213.

14. Inagaki M, Shibata K, Setou S, Toyoda M and Aizawa J I, Desalination, 2000, 128(3), 219.

15. Toyoda M, Nishi Y, Iwashita N and Inagaki M, Desalination, 2003, 151(2), 139.

16. Inagaki M, Nagata T, Suwa T and Toyoda M, New Carbon Mater., 2006, 21(2), 97. 
17. Pang X Y, Xu L J, Su Y J, Lv P and Liang X H, J Mater Sci Eng., 2008, 2(10), 49.

18. Pang X Y, E-J Chem., 2010, 7(4), 1258.

19. China State Bureau of Quality and Technical Supervision. The Chemical Analysis Method of Graphite GB/T 3521-1995. Beijing: Publishing house of Chinese standard, 1995, 1-10.

20. Country Environ. Prot. Bureau, Environmental Protection Industry Standard's Republic of China HJ/T 271-2006-Specifications for Environmental Protection Product Ultrafiltration Equipment, 2006.

21. Chiou M S, J Hazard Mater., 2002, 93, 233.

22. $\mathrm{Wu} \mathrm{Z} \mathrm{J,} \mathrm{Hyeonwoo} \mathrm{J} \mathrm{and} \mathrm{Kang} \mathrm{T} \mathrm{L,} \mathrm{Chem} \mathrm{Eng} \mathrm{J.,} \mathrm{2005,} \mathrm{112,} 227$. 


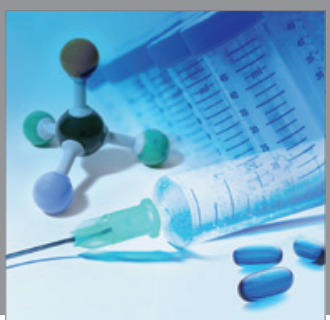

International Journal of

Medicinal Chemistry

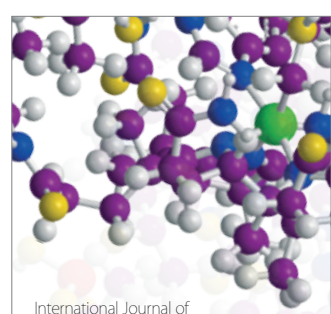

Carbohydrate Chemistry

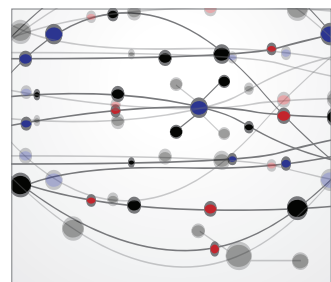

The Scientific World Journal
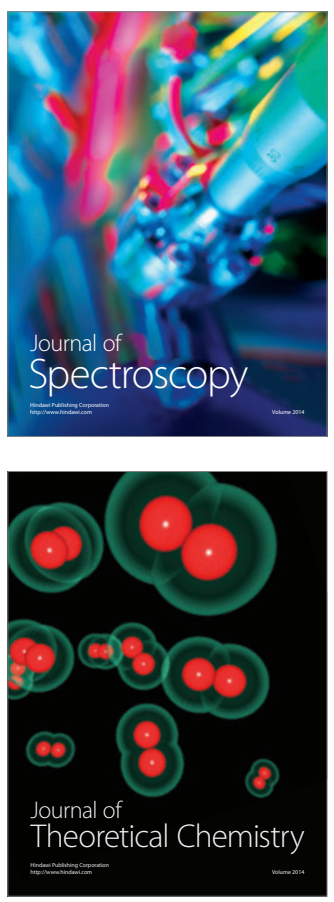
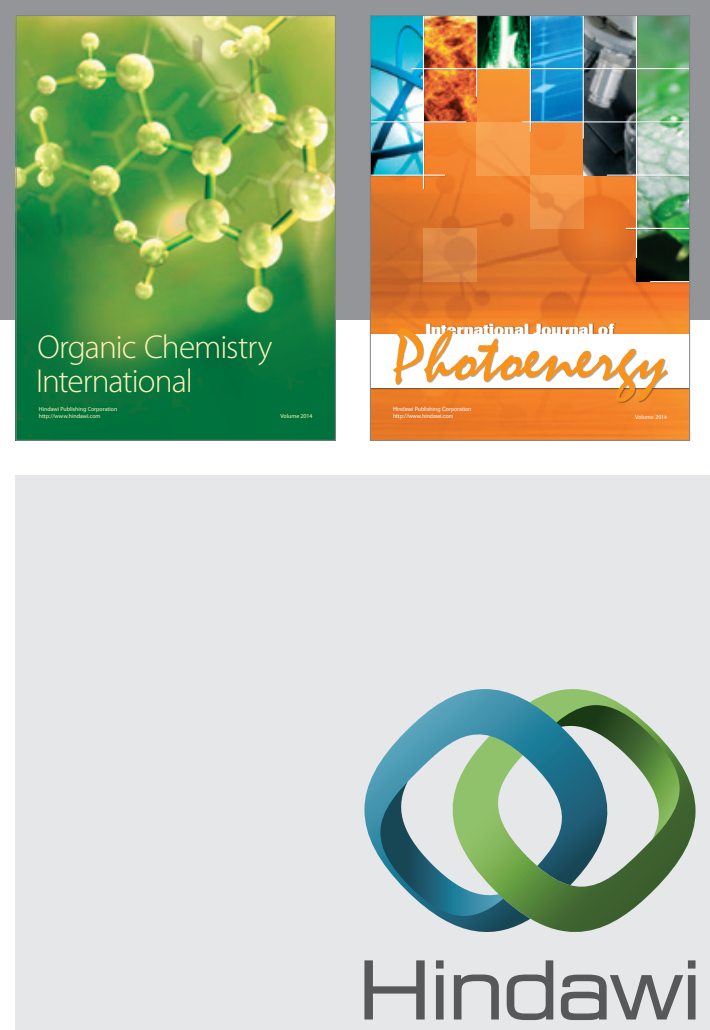

Submit your manuscripts at

http://www.hindawi.com
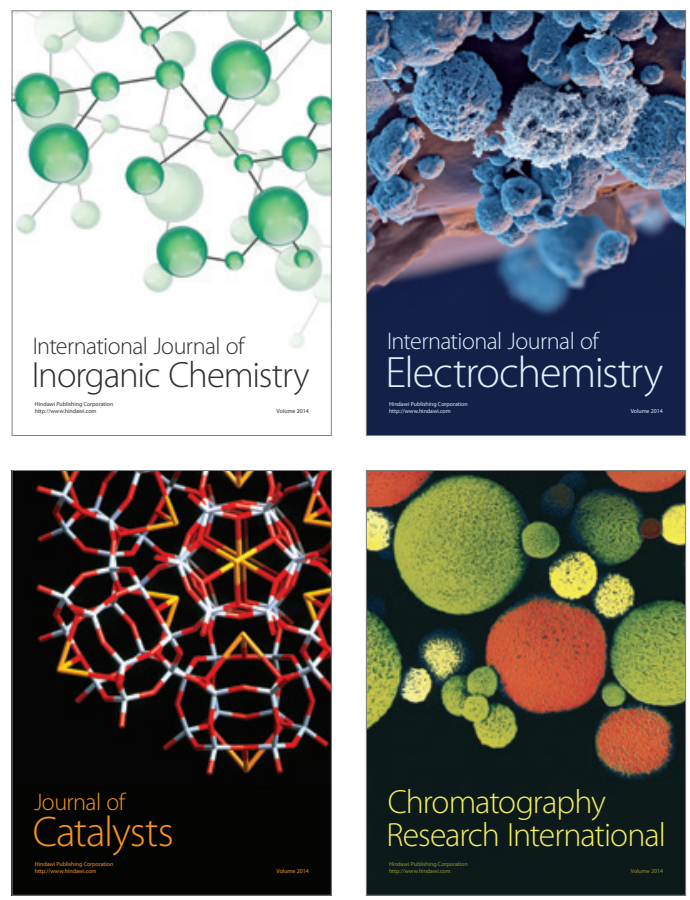
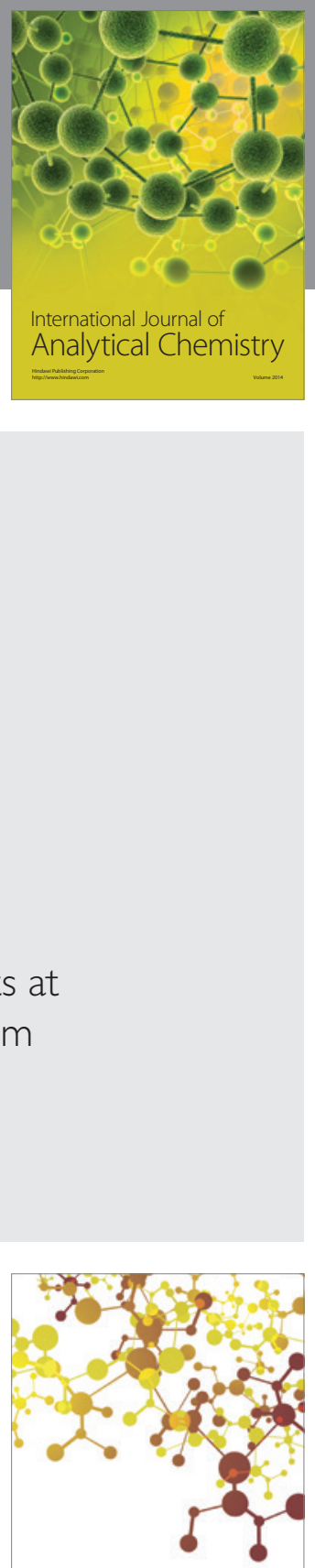

Journal of

Applied Chemistry
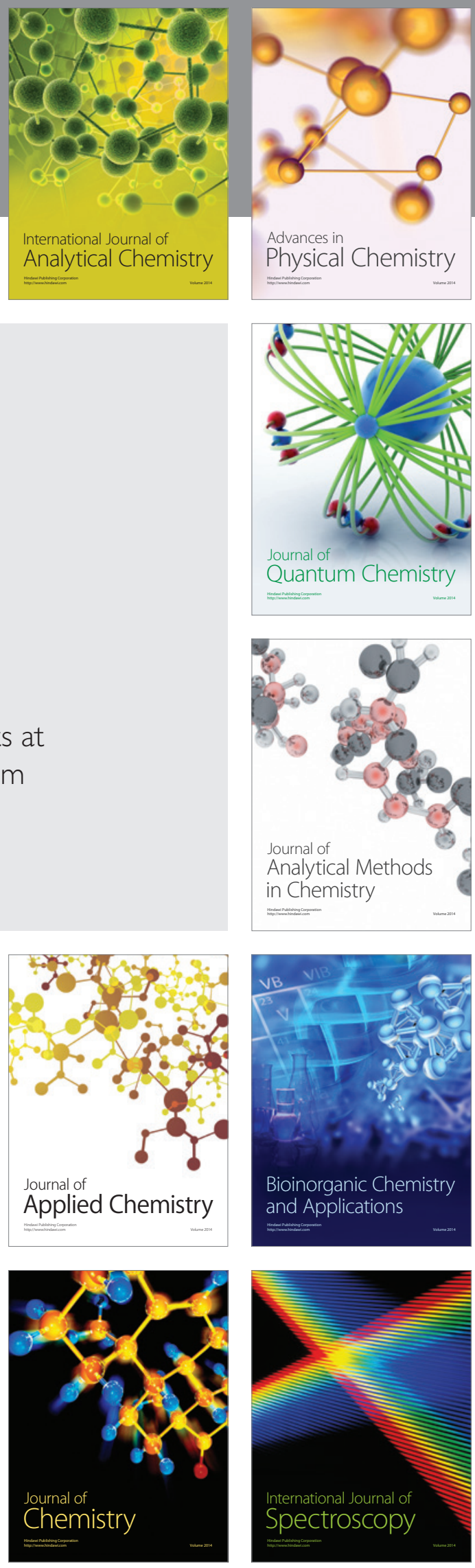